\title{
THE CONCEPT OF RES JUdiCATA IN THE COMMON LAW SYSTEM WITH EMPHASIS ON CYPRIOT AND UK PERSPECTIVES
}

\author{
Accepted \\ 28. 9. 2021 \\ Revised \\ 1. 12. 2021 \\ Published \\ 22. 12. 2021 \\ Keywords \\ res \\ judicata, \\ cause of \\ action \\ estoppel, \\ issue \\ estoppel, \\ abuse of \\ process, \\ common \\ law, \\ Republic of \\ Cyprus, \\ international \\ litigation
}

\author{
Demetra LOIZOU \& DesPina CHRISTOFi \\ University of Central Lancashire, Pyla, Cyprus. \\ E-mail: dloizou@uclan.ac.uk, dchristofi1@uclan.ac.uk \\ CORRESPONDING AUTHOR \\ dloizou@uclan.ac.uk
}

\begin{abstract}
The doctrine of res judicata is an important feature in many common law systems, most notably formulated in English law. This paper examines its rationale, purpose and scope under common law, with a focus on the cause of action estoppel and issue estoppel, before looking at its application in the legal system of the Republic of Cyprus. Cyprus owes much of its legal system to common law and thus possesses many similarities to the English formulation of the doctrine.
\end{abstract}




\section{$1 \quad$ Purpose and Rationale}

'The object of the rule of res judicata is always put upon two grounds— the one public policy, that it is in the interest of the state that there should be an end of litigation, and the other, the hardship on the individual, that he should be vexed twice for the same cause'

The doctrine of res judicata is a principle of litigation that ensures the finality of disputes in order to protect parties from being vexed with the same matter twice. The full Latin maxim of this term is res judicata pro veritate accipitur which essentially translates to 'a matter adjudged is taken as truth' (Clermont, 2016: p. 1069). Its purpose is essentially to honour the finality of a decision. It does this by ensuring that when a decision is handed down by a judicial or other tribunal with jurisdiction over the case, the same matter cannot be relitigated by the parties bound by the decision. The exception to this is if the decision were to be appealed. ${ }^{2}$

The doctrine is premised on two principles, namely, that the end to litigation is in the public interest (interest reipublicae ut sit finis litium) and that no one should be burdened twice by one and the same cause (nemo debet bis vexari pro una et eadem causa). ${ }^{3}$ Hence, res judicata supports 'the good administration of justice in the interests of the public and the parties by preventing abusive and duplicative litigation.' ${ }^{4}$ The public interest aspect is the prevention of any legal uncertainty that might arise from relitigation and the prevention of wasted time and resources. ${ }^{5}$ The same was emphasised in Wiltshire v Powell where Arden LJ noted that the doctrine 'promotes the important public policy of finality in legal proceedings and thus legal certainty.' ${ }^{6}$

\footnotetext{
${ }^{1}$ Lockyer v Ferryman, [1877] 2 App. Cas. 519, at 530 (H.L.).

${ }^{2}$ Christou v Haringey London Borough, [2013] EWCA Civ 178, [39] (Elias LJ).

${ }^{3}$ Fraser v HLMAD, Ltd, [2006] EWCA Civ 738.

${ }^{4}$ Virgin Atlantic Airways Limited v Zodiac Seats UK Limited, [2013] UKSC 46, [55] (Lord Neuberger).

5 id.

${ }^{6}$ Powell v Wiltshire, [2004] EWCA Civ 534, [36].
} 
As the ultimate means for enforcement of rights, certainty must be ensured in the process of court adjudication. As stated by Zuckerman, '[a]s long as [the] rights [of citizens] are susceptible to challenge in court, there is uncertainty about the outcome of the challenge and therefore, about the rights themselves' (Zuckerman, 2019: 25.1). This then contributes to the weakening of the rule of law if there is doubt over the rights one can enjoy. As such, closure rules, which place limitations on further litigation on matters that have already been decided, are imperative to the functioning of the judicial system. The importance of placing limits on the right of citizens to reopen disputes was emphasised by Lord Wilberforce; however, he also recognises that there is a balance that must be struck between finality and justice: 'Any determination of disputable fact may, the law recognises, be imperfect: the law aims at providing the best and safest solution compatible with human fallibility /.../ [then] closes the book. ${ }^{7}$ Yet, he acknowledges that by doing so, it prevents the reevaluation of fresh material that may arise, which could perhaps lead the case to a different outcome. Such a prospect may lead to the argument that the law prefers justice to the truth. However, he emphasises that the law strives to address this gap; it does so by allowing appeals. He is careful to note that 'there are some cases where the certainty of justice prevails over the possibility of truth $/ \ldots /$ it is these cases where the law insists on finality.'

In the first place, this paper will discuss the meaning and scope of the doctrine of res judicata under English law before proceeding to examine the place and role of the doctrine in the Cypriot legal system.

\section{Constituent Elements}

The key requirements to establish res judicata were outlined in $\mathrm{R}$ (on the application of Coke-Wallis) $v$ Institute of Chartered Accountants in England and Wales. ${ }^{9}$ These will be discussed in turn.

\footnotetext{
${ }^{7}$ Ampthill Peerage Case, [1977] A.C. 547, 569 (H.L.).

8 id.

${ }^{9}$ R. (on the application of Coke-Wallis) v Institute of Chartered Accountants in England and Wales, [2011] 2 A.C. 146, [34] (Lord Clarke JSC) (UKSC.). The judge referred to the constituent elements of res judicata as outlined in (Handley, 2009: 1.02).
} 


\subsection{The decision, whether domestic or foreign, must be judicial}

A judicial decision must be one given by a tribunal exercising judicial functions. This criterion excludes tribunals that act as administrative bodies and do not allow for an adversarial procedure, which includes the presentation of evidence by the opposing sides as well as the examination and cross-examination of witnesses. According to Lush J, 'no estoppel can arise from a decision of an administrative authority which cannot be classed as either "judicial" or as a "tribunal", and that an authority cannot be given either of those classifications if it /.../ is under no obligation to receive evidence or hear argument.'10

\subsection{Decision was, in fact, pronounced}

The earlier decision must have been formally delivered and came into force before the second action commenced. Therefore, pending decisions cannot fall under the scope of res judicata. The appropriate time for deciding whether the earlier decision establishes res judicata concerning a later decision is when the second action is heard on the merits and not before (subject to the law on the abuse of process, discussed below).

\subsection{Judicial body in question has jurisdiction}

According to this requirement, the court must have jurisdiction over the parties and the subject matter. If the court lacks such jurisdiction, no res judicata can arise $\mathrm{e}^{11}$ (Fentiman, 2015: 15.56).

\section{$2.4 \quad$ Must be final}

For res judicata to take effect, the decision handed down by the court with competent jurisdiction must be final. This does not depend on whether the decision can or cannot be appealed; a decision is treated as final when it

\footnotetext{
${ }^{10}$ Pastras v Commonwealth, [1966] 9 FLR 152 (Lush J) (Sup Ct of Victoria).

${ }^{11}$ Doberman v Watson, [2017] EWHC 1708 (Ch).
} 
is one that cannot be varied, reopened or set aside by the court that delivered it or any other court of co-ordinate jurisdiction, although it may be subject to appeal to a court of higher jurisdiction. ${ }^{12}$

are to be treated as res judicata because the investigation process has been discharged upon the parties' consent. Further, with regard to judgments in default, they are to be treated as a final judgment unless and until they are set aside. ${ }^{13}$ Moreover, the fact that a judgment is pending appeal when resjudicata is being invoked does not prevent the judgment from being final. ${ }^{14}$

Foreign judgments must be treated as final in their jurisdiction to ground estoppel in the United Kingdom, as 'it would be absurd to hold a party bound by issues decided in a foreign court if those issues could be re-opened in that country.' ${ }^{15}$

\subsection{Must be on the merits}

The meaning of a decision 'on the merits' was discussed by the House of Lords in The Sennar (No. 2). According to the court, a decision on the merits is 'a decision which established certain facts as proved or not in dispute; states what are the relevant principles of law applicable to such facts; and expresses a conclusion with regard to the effect of applying those principles to the factual situation concerned.'16

It is important to note that the mere fact that a dispute is not the subject of a full argument does not preclude the resulting decision from being on the merits. In The Sennar (No. 2), it was held that the procedural decision of the Dutch court that it had no jurisdiction to adjudicate upon the appellants' claim could give rise to an issue estoppel in the English courts. According to Lord Brandon, the argument that a procedural decision is not a decision on the merits is a misconception of the term ${ }^{17}$ (Malek, Bagshaw, 2020: 46.06). As such, decisions that determine an issue (other than being issued solely on procedural grounds) count as decisions on the merits, even if not all issues in the dispute between the parties have been determined. This

\footnotetext{
12 DSV Silo-und Verwaltungsgesellschaft mbH v Sennar, The Sennar (No. 2), [1985] 1 W.L.R 490 , 494 (Q.B.) (Diplock LJ). See also: Malek H.M., Auburn J., Bagshaw R., et al. (eds). (2020) Phipson on Evidence I: 19th ed (UK: Sweet \& Maxwell Ltd) p. 43-03.

${ }^{13}$ New Brunswick Ry v British and French Corp, [1939] A.C. 1 (H.L.).

${ }^{14}$ Scott v Pilkington, [1862] 121 E.R. 978 (Q.B.).

15 Kirin-Amgen Inc v Boehringer Mannheim GmbH, [1997] F.S.R. 289, 312 (Aldous LJ) (C.A.).

${ }^{16}$ The Sennar (No. 2), [1985] 1 W.L.R at 499 (Brandon LJ).

17 id.
} 
means that for a decision to be on the merits, it does not need to fully determine the parties' substantive rights. Fentiman states that in essence, 'a decision on the merits is a decision on the merits of an argument, not of substantive rights. In practice, however, $/ \ldots /$ the scope for applying [this doctrine] to a decision of a procedural nature will be limited' (Fentiman, 2015: 15.20). ${ }^{18}$

\subsection{Privies}

The parties in both proceedings must be the same; there is usually no difficulty establishing who is privy; that is, any person with a legal or beneficial interest in the earlier proceedings or their subject matter. It is for the person seeking to rely on the doctrine to establish the issue of privy. ${ }^{19}$

Privies include all those who succeed to the rights and/or liabilities of a party to the proceedings upon death, insolvency, by statute or assignment or those identified in estate or interest. Who is to be considered privy will depend on the facts of the case in question. ${ }^{20}$

\section{The Scope of the Doctrine}

The practical manifestations of the objective of finality are far from straightforward and are not sharply distinguished. It is important to note that res judicata is a broad, all-encompassing term, as it embraces both 'cause of action estoppel' and 'issue estoppel' amongst others that fall within its purview. ${ }^{21}$

A plea of res judicata stipulates that once 'the res - the thing actually or directly in dispute - has been already adjudicated upon, / . . / by a competent court, it cannot be litigated again.'22 In other words, a decision by a competent court gives rise to estoppel and the parties to the proceedings in question are barred or estopped from disputing the issue in other proceedings. However, it does not bar a non-party who is not bound by the results of the proceedings, nor does it bar a person who has participated in a different capacity. Zuckerman gives the example of a person who sues as a personal representative of the deceased. In this case, this individual is not

\footnotetext{
${ }^{18}$ See also: Desert Sun Loan Corp v Hill, [1996] C.L.C 1132, 1139 (C.A.).

${ }^{19}$ Carl-Zeiss, [1967] 1 A.C. 853.

${ }^{20}$ MCC Proceeds Inc v Lehman Brothers International (Europe), [1998] 4 All E.R. 675 (C.A.).

${ }^{21}$ Virgin Atlantic, [2013] UKSC 46 at [17] - [18].

22 Ord v Ord, [1923] 2 K.B. 432, 439 (Lush LJ).
} 
bound by the findings made in the initial proceedings in which he sued in a personal capacity. 23

Through the doctrine of estoppel, the power of estoppel then branches out into two distinct rules, known as cause of action estoppel and issue estoppel, which fall under the purview of res judicata. ${ }^{24}$ They share a common rationale that stems from the exhaustion of resources. When money and time are invested into litigation, parties to the litigation are entitled to peace coming from the final judgment and knowing that no further legal challenges will arise (Zuckerman, 2019: 25.65).

\subsection{Lord Sumption's Six Principles - Overview}

The modern formulation of the doctrine of resjudicata is encapsulated in the Supreme Court decision of Virgin Atlantic. Lord Sumption, who gave the leading judgment, identified the six general principles that together comprise the doctrine. Two of these principles concern 'cause of action estoppel' and 'issue estoppel', respectively.

Lord Sumption first identified what is known as 'cause of action estoppel', which he described as 'a form of estoppel precluding a party from challenging the same cause of action in subsequent proceedings.' 25 The parties are estopped from denying or asserting the particular cause in any other proceedings which involve the parties (Zuckerman, 2019: 25.64, No. 8).

Second, albeit not formally a species of estoppel, is a situation where 'the claimant has succeeded in the first action and does not challenge the outcome.'26 In such a case, the claimant is barred from bringing a second action on the same cause of action to recover further damages. ${ }^{27}$

Third, he identifies the 'doctrine of merger', which extinguishes a cause of action once judgment has been given upon it. To this effect, the claimant solely retains a right upon the judgment. The judge points out that although this principle produces the same outcome as the second principle above, it is, in fact, a substantive rule

\footnotetext{
${ }^{23}$ Marginson v Blackburn Borough Council, [1939] 2 K.B. 426.; Zuckerman, Civil Procedure, 25.66 (see No. 8).

${ }^{24}$ Virgin Atlantic, [2013] UKSC 46 at [17] - [18].

${ }^{25}$ Virgin Atlantic, [2013] UKSC 46 at [17].

${ }^{26}$ Virgin Atlantic, [2013] UKSC 46 at [17].

${ }^{27}$ Conquet v Boot, [1928] 2 K.B. 336.
} 
about the legal effect of an English judgment, which is 'of a higher nature' and supersedes any underlying cause of action..$^{28}$

Fourth, there is the principle of 'issue estoppel'. ${ }^{29}$ The latter arises when an issue in the cause of action that was essential to the final resolution of the proceedings and has already been decided is reopened in subsequent proceedings, between the same parties and involving a different cause of action to which the same issue is relevant. 30 The parties will be unable to advance any arguments that are inconsistent with the findings in the initial proceedings, even if the subsequent proceedings relate to a different cause of action.

Fifth is the 'Henderson Abuse' principle, as it was first formulated in the case of Henderson $v$ Henderson by Wigram V-C 31 (Butterworth, 2009: p. 1179). The abuse of process principle prevents a party from raising a matter in subsequent proceedings that should and could have been raised in the previous proceedings. Lastly, there is the more general procedural rule against abusive proceedings, which informs all the other principles, with the possible exception of the doctrine of merger. ${ }^{32}$

Under English law, re-litigation is principally governed by cause of action estoppel and issue estoppel, which shall be further examined below. As stated above, the doctrine of res judicata also extends to decisions of foreign courts. In this respect, the following requirements must be satisfied to preclude re-litigation: (i) the foreign judgement must be effective; (ii) the parties must be the same; (iii) the foreign adjudication must be on the merits (Fentiman, 2015: 15.06 and 15.07). ${ }^{33}$ Once satisfied, the outcome of the proceedings has the effect of res judicata because 'procedural fairness so requires' (Fentiman, 2015: 15.07).

\footnotetext{
${ }^{28}$ Virgin Atlantic, [2013] UKSC 46 at [17], quoting King v Hoare, [1844] 13 M. \& W. 494, 504 (Ex).

${ }^{29}$ This term was first formulated by Higgins J in Hoysted v Federal Commissioner of Taxation, [1921] 29 CLR 537, 561 (H.C.A).

30 Thoday v Thoday, [1964] P.181, 197-198 (C.A.).

31 Henderson v Henderson, [1843] 3 Hare 100 [115] (Ch.).

32 Virgin Atlantic, [2013] UKSC 46 at [17].

33 The Sennar (No. 2), [1985] 1 W.L.R 490.
} 


\subsection{Cause of Action Estoppel}

The 'cause of action estoppel' is a rule 'which prevents a party to an action from asserting or denying, as against the other party, the existence of a particular cause of action, the non-existence or existence of which has been determined by a court of competent jurisdiction in previous litigation between the same parties.' 34 It bars a party from relitigating a claim they have lost (other than by appeal), even if they can now show that the earlier decision was wrong. ${ }^{35}$

It arises when a cause of action in later proceedings is identical to the cause of action raised in earlier proceedings. ${ }^{36}$ This can be seen to reinforce the Latin maxim nemo devet bis vexari pro una et eadem causa, with causa bearing its Latin meaning. Once it is established that a cause of action is identical, it cannot be advanced again under any circumstances, not even to claim a new relief that could not have been claimed in the initial proceedings (Zuckerman, 2019: 25.84, No. 8). The prohibition against pursuing a claim again is absolute (but only concerning the points that were actually decided on an earlier occasion $)^{37}$ and cannot be waived even if new evidence has been discovered or the law has been changed (Zuckerman, 2019: 25.84, No. 8). In effect, there is no option to set aside the original judgment, with the exception of allegations of fraud or collusion. 38

\subsection{Issue Estoppel}

First coined by Higgins J in Hoystead $v$ Taxation Commissioners, issue estoppel arises where an issue arises in subsequent proceedings that has already been decided in a previous action. ${ }^{39}$ As such, a party cannot advance an argument of fact or of law that conflicts with the earlier decision. The earlier decision acts as estoppel.

The issue must be such that it forms a necessary ingredient in a cause of action; once litigated and decided, it becomes final and cannot be reopened in subsequent

\footnotetext{
34 Thoday, [1964] P.181 at 197-198; Zuckerman, Civil Procedure, 25.83.

35 Arnold v National Westminster Bank Plc, [1991] 2 A.C. 93, 104 (H.L.).

${ }^{36}$ Buehler AG v Chronos Richardson Ltd, [1998] 2 All E.R. 960 (C.A.).

${ }^{37}$ Coflexip SA v Stolt Offshire MS Ltd, [2004] EWCA Civ 21 (C.A.).

38 Arnold, [1991] 2 A.C. at 104.

${ }^{39}$ Hoysted, 1921] 29 CLR 537.
} 
proceedings by the same parties involving a different cause of action, even if the same issue is relevant to the subsequent cause of action. ${ }^{40}$

As explained by Lord Diplock

'... a party to civil proceedings is not entitled to make, as against the other party, an assertion, whether of fact or of the legal consequences of facts, the correctness of which is an essential element in his previous cause of action or defence in previous civil proceedings between the same parties $/ . . /$ and was found by a court of competent jurisdiction /.../ to be incorrect.' ${ }^{41}$

The exception to this is a situation where further material which is relevant to the correctness of the assertion and could not have been reasonably adduced by that party in previous proceedings becomes available. ${ }^{42}$ The rationale for excluding from the ambit of issue estoppel issues that are not essential for determining a cause of action or defence rests on two grounds. First, it would be unfair to hold parties bound by a decision they were not obliged to litigate. Second, if issue estoppel extended to non-essential issues, parties would be prompted to pursue unimportant issues instead of concentrating on the essential ones, thus inflating unnecessary costs and causing delays (Zuckerman, 2019: 25.88, No. 8).

Unlike cause of action estoppel, issue estoppel can be circumvented in certain situations. Through a weighing exercise, the courts assess whether the injustice of not allowing the essential issue to be re-litigated outweighs the disadvantage that the opponent will suffer by losing the benefits established in earlier proceedings. ${ }^{43}$

\subsection{Abuse of Process}

The public interest in finality is not only reflected in the doctrine of res judicata but also in the judicial system's inherent jurisdiction to prevent an abuse of its process. This discretionary jurisdiction can be applied in cases where neither cause of action estoppel nor issue estoppel apply, and the litigation in question would be contrary

\footnotetext{
${ }^{40}$ Arnold, [1991] 2 A.C. at 105.

${ }^{41}$ Mills v Cooper, [1967] 2 Q.B. 459, 468-469 (Diplock LJ).

42 id.

43 Arnold, [1991] 2 A.C. at 103.
} 
to the public interest. In such cases, the court can invoke its discretionary jurisdiction to prevent litigation on those matters (Zuckerman, 2019: 25.68, No. 8). Unlike the doctrine of res judicata, this inherent power of the court is not subject to strict application nor is it confined by rules; rather, it is left open and flexible for the court to reply depending on the circumstances of the case, in accordance with the dictates of public policy. ${ }^{44}$ This jurisdiction particularly applies to causes of action or issues that could have been raised or decided in earlier proceedings but were not, and, secondly, where a party not bound by the earlier proceedings relies upon it. It thereby prevents causes of action or issues from being brought up again and reinforces the public interest rationale by ensuring that the court does not exhaust its limited resources or vex litigants with repeated proceedings which the court has already given time and regard to (Zuckerman, 2019: 25.69, No 8). The distinction between res judicata and abuse of process was summarised in Virgin Atlantic: 'Res judicata and abuse of process are juridically very different. Res judicata is a rule of substantive law, while abuse of process is a concept which informs the exercise of the court's procedural powers. ${ }^{\prime} 5$ Although distinct, they overlap in the sense that they both have the same underlying purpose of limiting abusive and duplicative litigation. The general policy underpinning the abuse of process principle is to ensure that litigants do not advance causes of action that they could have advanced in earlier proceedings. The leading authority for this is Henderson $v$ Henderson:

'...the Court requires the parties to that litigation to bring forward their whole case, and will not (except under special circumstances litigation in respect of matter which might have been brought forward as part of the subject in contest, but which was not brought forward, only because they have, from negligence, inadvertence or even accident omitted part of their case. The plea of res judicata applies, except in special cases, not only to points upon which the court was actually required by the parties to form an opinion and pronounce a judgment, but to every point which properly belonged to the subject of litigation and which the parties, exercising reasonable diligence, might have brought forward at the time.'46

\footnotetext{
${ }^{44}$ Hunter v Chief Constable of West Midlands, [1982] A.C. 529, 536 (H.L.).

${ }^{45}$ Virgin Atlantic, [2013] UKSC 46 at [27] (Sumption LJ).

46 Henderson, [1843] 3 Hare at [115] (Wigram V-C).
} 
The doctrine of res judicata has a long history under English common law. Over the years, several cases have developed, advanced and refined the doctrine, culminating in its modern formulation as encapsulated in the Virgin Atlantic case. The question to be discussed in the second part of the paper concerns the meaning and scope of res judicata in the Cypriot legal order and whether any material differences exist or have come to arise between the two legal orders. To this effect, comparisons will be made as and when appropriate.

\section{$4 \quad$ Res Judicata in Cypriot Law}

Cyprus' common law jurisdiction lingers on from its British colonial heritage. It is, however, considered a mixed system as it also features elements of civil law in its body of public law (Hatzimihail, 2013: p. 38). The common law identity of the Cypriot legal system is evident as a matter of both law and practice. Section 29 of the Courts of Justice Law sets out the applicable law to be applied by every Cypriot court in both civil and criminal proceedings. ${ }^{47}$ The provision includes common law and the principles of equity among the sources of law 'save in so far as other provision has been or shall be made by any Law and so far as not inconsistent with the Constitution.'48 According to Loizou J, judge of the Supreme Court of Cyprus, the doctrine of precedent is 'part and parcel of our judicial system'.49 To this effect, all the lower courts are bound by the existing judicial precedents of the Supreme Court.

As such, the doctrine of res judicata has been weaved into Cypriot law, with its caselaw largely mimicking the principles and formulations set out by English law; a few notable cases examined below have been chosen to highlight the similarities. The application of the doctrine, therefore, mirrors that of English law as it prohibits the parties in an action from relitigating a matter with respect to which a decision has already been delivered by the court. The impact of res judicata is all-encompassing. For example, according to a 2018 report by the Supreme Court of Cyprus for the Association of the Councils of State and Supreme Administrative Jurisdiction of the European Union (ACA), '[j] udgments issued are final and will require the force of res judicata' (Supreme Court of Cyprus, 2018: 29). At the same time, the report links

\footnotetext{
${ }^{47}$ Courts of Justice Law, 14/1960 (1960).

48 id., section 29(1)(c).

${ }^{49}$ Republic v Demetriades, [1977] 3 CLR 213 (Supreme Court of Cyprus).
} 
the concept of res judicata with the principle of stare decisis by stating immediately afterwards: '[t]he principle of stare decisis applies to all judgments of the Supreme Court' (Supreme Court of Cyprus, 2018: 29). In this respect, the report cites section 59 of the Law on the General Principles of Administrative Law, which states that '[t]he decisions of the Supreme Court have the force of res judicata." 50

Another notable example involves the application of res judicata to arbitral awards. In particular, the District Court of Nicosia referred to the leading English case law (Carl Zeiss) to interpret the meaning of 'finality' and deliver its judgment. ${ }^{51}$ This further strengthens the prominence of common law in the Cypriot judicial system. Following the foundations of English law, the two principles underpinning the doctrine of res judicata in the Cypriot system are the interest rei publicae ut sit finis litium (the res judicata of a dispute is in the public interest) and the nemo debet bis vexani pro eadem causa (no one should be harassed twice for the same matter), as affirmed in the case of Acuac Inc. v Frederickou Schools Co. Limited and Michael Frederickou. 52

Its public interest standpoint is strong as it also serves to prevent the submission of numerous claims, straining not only the court's limited resources but also the willingness of the parties in the proceedings. For that purpose, the doctrine extends to cover all causes of action that a party could include in their lawsuits following a reasonably thorough investigation. A failure to do so deprives the party of the right to bring a new claim. The rule applies not only to matters that had been considered in the first proceedings but also to any matter closely connected with that procedure, which the parties, with reasonable caution, could have raised. Thus, once a judgment is res judicata, the same dispute cannot be relitigated. A thorough examination of this doctrine was developed in the case of Fofis Iliadou-Kalisperav Sokerati Iliadi and other ${ }^{53}$ and additionally summarised in Acuac Inc v Frederickou Schools.

\footnotetext{
${ }^{50}$ Law on the General Principles of Administrative Law, Law 158(I)/1999, section 59(1) (1999).

${ }^{51}$ Cruz City 1 Mauritius Holdings v Arsanovia Limited, General Application No. 322/2014 (Nicosia District Court. 2015).

52 Acuac Inc. v Frederickou Schools Co. Limited and Michael Frederickou, Case No. 8809/03 and 4036/08 (Nicosia District Court. 2014).

${ }^{53}$ Fofis Iliadou- Kalispera v Sokrati Iliadi and others, Case No. 4675/04 (Nicosia District Court. 2009).
} 
More recently, the District Court of Nicosia decided to strike a claim for abusing the process of the court. ${ }^{54}$ As stated by the firm which acted for the defendants, the case has legal significance because 'this is the first time in which a Cypriot Court has applied the Henderson rule in solitude and has accepted it as a rule capable of operating on its own, without the need for it to be hinged on res judicata' (Demetriou, 2021). This echoes the distinction drawn by Lord Justice Sumption between res judicata and abuse of process in the case of Virgin Atlantic.

As a judicial system that continues to experience a growing backlog of cases due to its low and declining clearance rate, especially as regards civil cases (International Monetary Fund, 2017; Institute of Public Administration (IPA), 2018), the doctrine's acceptance into the Cypriot judicial system has the potential of strengthening the ability of Cypriot courts to use judicial time more effectively and efficiently, instead of wasting time on multiple proceedings.

\section{$5 \quad$ Conclusion}

Res judicata is a key tool for preserving good administration of justice by preventing duplicative litigation, which means duplication of time and resources. At the same time, the doctrine of resjudicata contributes to the protection of legal certainty, which is in the public interest. The analysis above illustrates the common approach of English and Cypriot law to the application of res judicata doctrine, which further reflects similar trends in English and Cypriot approaches in the area of civil and commercial litigation. While it is well established that Cypriot civil and commercial litigation rules share the skeleton with corresponding English rules, amendments and changes have been implemented concerning most aspects of the rules in light of the evolution of the two legal systems. The doctrine of res judicata is an exceptional case where the English approach is being followed in Cyprus without any substantial differences, which further shows that the particular doctrine is well-founded and of timeless value.

\footnotetext{
${ }^{54}$ Toumazou a.o. v Nicodemou \& Gavrias Construction Co Ltd, Case No. 880/2018 (Nicosia District Court. 2020).
} 


\section{Acknowledgement}

The authors would like to thank Yomna Zentani for her contribution to the research and editing of this paper.

\section{References}

Butterworth. (2009) Halsbury's Laws Vol 12, 5th ed. (UK: Butterworth).

Clermont M. Kevin. (2016) Res Judicata as Requisite for Justice, Rutgers University Law Review, 68, p. 1067 - 1139, https://scholarship.law.cornell.edu/cgi/viewcontent.cgi?article=2599\&context=facpub.Dem etriou, Theo. Cypriot court prevents abuse of process by adopting the "Aldi requirement" and the rule in Henderson v Henderson, accessed September 18, 2021, https://www.idlaw.com.cy/knowledge/cypriot-court-prevents-abuse-of-process-byadopting-the-aldi-requirement-and-the-rule-in-henderson-v-henderson/.

Fentiman R. (2015) International Commercial Litigation. 2nd ed. (Oxford: Oxford University Press).

Handley K. R.(2009) Spencer Bower and Handley: Res Judicata. 4th ed. (UK: Lexis Nexis Butterworths).

Hatzimihail N. (2013) Cyprus as a Mixed Legal System, Journal of Civil Law Studies, 6, no. 1, p. 38 96, https://digitalcommons.law.lsu.edu/jcls/vol6/iss1/3.

Institute of Public Administration (IPA). (2018) Functional Review of the Courts System of Cyprus, https://www.cyprusbarassociation.org/files/publications/Functional_Review_of_Courts_Sy stem_of_Cyprus_IPA_Ireland_-_Final_Report.pdf.

International Monetary Fund. European Dept. (2017) Cyprus: Selected Issues, IMF Staff Country Reports, no. 376, https://doi.org/10.5089/9781484332757.002.

Malek H. M., Auburn J., Bagshaw R., et al. (eds). (2020) Phipson on Evidence I: 19th ed (UK: Sweet \& Maxwell Ltd).

Supreme Court of Cyprus. (2018) Administrative Justice in Europe, 29, https://www.acaeurope.eu//en/eurtour/i/countries/cyprus/cyprus_en.pdf.

Zuckerman A. (2019) Civil Procedure: Principles of Practice. 3rd ed. (UK: Sweet \& Maxwell Ltd). 
